Keywords: Cement, grout, saltstone, slag, $K_{d}$ value, distribution coefficient, solubility, Eh, technetium

Retention: Permanent

\title{
Technetium Sorption by Cementitious Materials Under Reducing Conditions
}

\author{
Shanna L. Estes, ${ }^{\text {a }}$ Yuji Arai, ${ }^{b}$ Daniel I. Kaplan, ${ }^{\mathrm{c}}$ and \\ Brian A. Powell ${ }^{\mathrm{a}}$
}

a Environmental Engineering and Earth Sciences, Clemson University

b College of Agriculture, Forestry and Life Sciences, Clemson University

c Savannah River National Laboratory

January 2012

Savannah River National Laboratory Savannah River Nuclear Solutions, LLC Aiken, SC 29808

Prepared for the U.S. Department of Energy under

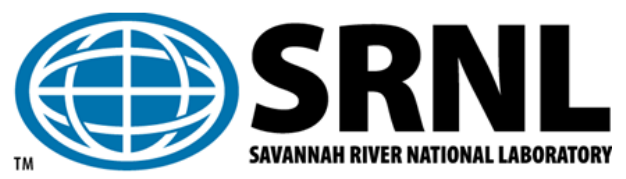
contract number DE-AC09-08SR22470. 


\section{DISCLAIMER}

This work was prepared under an agreement with and funded by the U.S. Government. Neither the U.S. Government or its employees, nor any of its contractors, subcontractors or their employees, makes any express or implied:

1. warranty or assumes any legal liability for the accuracy, completeness, or for the use or results of such use of any information, product, or process disclosed; or

2. representation that such use or results of such use would not infringe privately owned rights; or

3. endorsement or recommendation of any specifically identified commercial product, process, or service.

Any views and opinions of authors expressed in this work do not necessarily state or reflect those of the United States Government, or its contractors, or subcontractors.

Printed in the United States of America

Prepared for U.S. Department of Energy 


\section{REVIEWS AND APPROVALS}


SRNL-STI-2011-00716

Revision 0

\section{EXECUTIVE SUMMARY}

The objective of this study was to measure Tc sorption to cementitious materials under reducing conditions to simulate Saltstone Disposal Facility conditions. Earlier studies were conducted and the experimental conditions were found not to simulate those of the facility. Through a five month subcontract with Clemson University, sorption of ${ }^{99} \mathrm{Tc}$ to four cementitious materials was examined within an anaerobic glovebag targeting a $0.1 \% \mathrm{H}_{2}(\mathrm{~g}) / 99.9 \% \mathrm{~N}_{2}(\mathrm{~g})$ atmosphere. Early experiments based on Tc sorption and Eh indicated that $0.1 \% \mathrm{H}_{2}(\mathrm{~g})$ (a reductant) was necessary to preclude experimental impacts from $\mathrm{O}_{2}(\mathrm{~g})$ diffusion into the glovebag. Preliminary data to date (up to 56 days) indicates that sorption of ${ }^{99}$ Tc to cementitious materials increased with increasing slag content for simulated saltstone samples. This is consistent with the conceptual model that redox active sulfide groups within the reducing slag facilitate reduction of $\mathrm{Tc}(\mathrm{VII})$ to $\mathrm{Tc}(\mathrm{IV})$.

These experiments differ from previous experiments where a $2 \% \mathrm{H}_{2}(\mathrm{~g})$ atmosphere was maintained (Kaplan et al., 2011 (SRNL-STI-2010-00668)). The impact of the $2 \% \mathrm{H}_{2}$ (g) reducing atmosphere on this data was examined and determined to cause the reduction of Tc in experimental samples without slag. In the present ongoing study, after 56 days, Tc sorption by the 50-year old cement samples (no slag) was undetectable, whereas Tc sorption in the cementitious materials containing slag continues to increase with contact time (measured after 1, 4, 8, 19 and 56 days). Sorption was not consistent with spike concentrations and steady state has not been demonstrated after 56 days. The average conditional $\mathrm{K}_{\mathrm{d}}$ value for the Vault 2 cementitious material was 6,362 $\mathrm{mL} / \mathrm{g}$ (17\% slag), for the TR547 Saltstone ( $45 \%$ slag) the conditional $\mathrm{K}_{\mathrm{d}}$ was $1258 \mathrm{~mL} / \mathrm{g}$, and for TR545 (90\% slag) the conditional $\mathrm{K}_{\mathrm{d}}$ was $12,112 \mathrm{~mL} / \mathrm{g}$. It is anticipated that additional samples will be collected until steady state conditions are established to permit measuring more representative $\mathrm{K}_{\mathrm{d}}$ and solubility values under these experimental conditions. 


\section{TABLE OF CONTENTS}

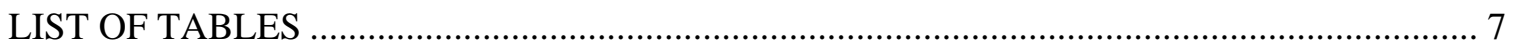

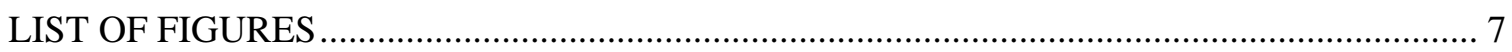

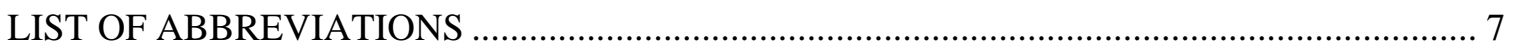

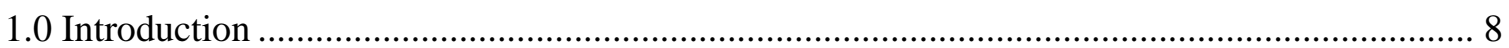

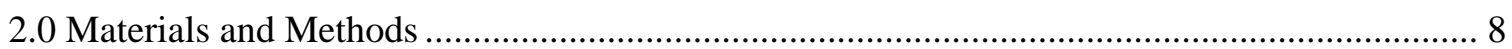

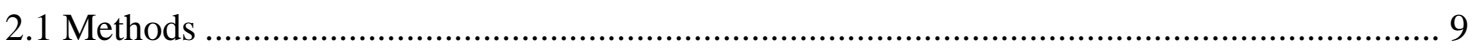

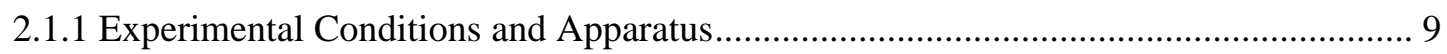

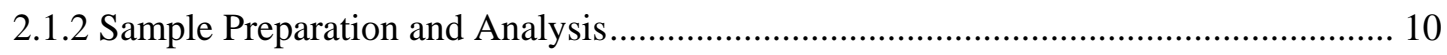

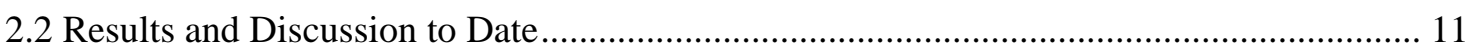

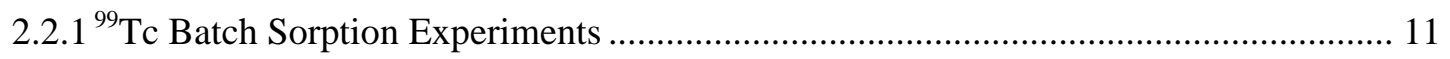

2.2.2 Submission of Proposal for XAS Beamline Time........................................................... 15

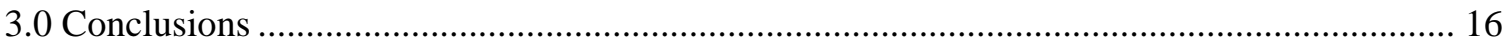

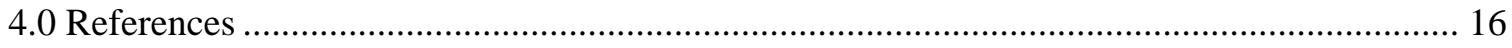

Appendix A: Submitted X-ray Absorption Spectroscopy Proposal .............................................. 18

Appendix B: Data for Tc-99 Fraction Sorbed and $\mathrm{K}_{\mathrm{d}}$ Values .................................................... 22 
SRNL-STI-2011-00716

Revision 0

\section{LIST OF TABLES}

Table 1. Saltstone reduction capacity and slag content (Lilley et al. 2009).

\section{LIST OF FIGURES}

Figure 1. Fraction of ${ }^{99} \mathrm{Tc}$ sorbed as a function of time and cementitious materials. X-axis labels note which cementitious material was used and the total ${ }^{99}$ Tc concentration........................ 12

Figure 2. Conditional $\mathrm{K}_{\mathrm{d}}$ values (i.e., non-equilibrium) as a function of time measured for ${ }^{99} \mathrm{Tc}$ sorption to cementitious materials. $\mathrm{X}$-axis labels note which cementitious material was used and the total ${ }^{99}$ Tc concentration.

Figure 3. $\mathrm{pH}$ of cementitious material suspensions measured during ${ }^{99} \mathrm{Tc}$ sorption experiments. 14

Figure 4. Redox potentials (converted to SHE) of cementitious material suspensions measured

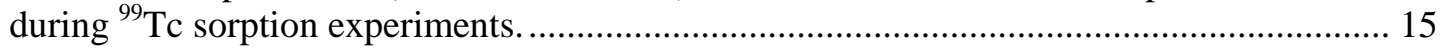

\section{LIST OF ABBREVIATIONS}

$\begin{array}{ll}\text { BFS } & \text { Blast furnace slag } \\ \text { DDI } & \text { Distilled deionized } \\ \text { ICP-MS } & \text { Inductive couple plasma-mass spectroscopy } \\ \text { K }_{d} & \text { Distribution coefficient } \\ \text { SRNL } & \text { Savannah River National Laboratory } \\ \text { XAS } & \text { X-ray Absorption Spectroscopy }\end{array}$


SRNL-STI-2011-00716

Revision 0

\subsection{Introduction}

Technetium is among the key risk drivers at the Saltstone Facility. It is immobilized in saltstone by (1) minimizing diffusion within the pore spaces of the cementitious wasteform, and (2) promoting the reduction of the highly mobile Tc(VII) form to a highly immobile Tc(IV) form by blast furnace slag. Kaplan et al. (2011; reporting the thesis work by Lilley (2010)) attempted to measure its equilibrium constant by conducting (ad)sorption $\mathrm{TcO}_{4}^{-}$studies in a glovebag. The objective was to measure the distribution coefficient, $K_{d}$ value, between solid phase saltstone and the aqueous phase. It became apparent that too reducing a condition had been created by the $\mathrm{H}_{2}$ gas, when experimental results showed the slag-free cementitious controls removed as much Tc from solution as the slag-containing cementitious materials. The objective of this study was to perform the original study with a less reducing condition to experimentally create and control redox conditions that are more representative of the interior saltstone material where oxygen gas levels are calculated to be at or near $0 \%$.

This is a status report and reflects work completed between May 5 and September 30, 2011. At the time of the last sample, steady state conditions have not been demonstrated. It is anticipated that this work will continue in the following year to permit measurement of steady state solubility and/or $\mathrm{K}_{\mathrm{d}}$ values.

\subsection{Materials and Methods}

There were four different cementitious formulations selected for this sorption study (Table 1). The first, referred to as Aged Cement, is a 50 year old sample that does not contain any reducing slag. The Vault 2 formulation contains 17\% reducing slag. The TR547 and TR545 saltstone formulations contain $45 \%$ and $90 \%$ reducing slag, respectively. In the case of the Vault 2 sample, effort was made to remove the larger aggregate prior to analysis, but the sand remained with the cement, slag, and fly ash. The composition of the Aged Cement is not known. No precautions were made to store the reducing-cementitious samples in an inert environment since fabrication four years ago, so it is anticipated that some oxidation of these samples occurred. At the start of the study the ground saltstone samples were primarily greenish gray and not dark black. 
Table 1. Saltstone reduction capacity and slag content (Lilley et al. 2009).

\begin{tabular}{|c|c|c|c|c|c|}
\hline Sample & $\begin{array}{c}\text { Percent } \\
\text { Reducing } \\
\text { Slag (dry wt- } \\
\% \text { ) }\end{array}$ & $\begin{array}{c}\text { Percent } \\
\text { Portland } \\
\text { Cement } \\
\text { (dry wt-\%) }^{\text {(c) }}\end{array}$ & $\begin{array}{c}\text { Percent Fly } \\
\text { Ash } \\
\text { (dry } \underset{\text { (c) }}{\text { wt-\%) }}\end{array}$ & $\begin{array}{c}\text { Percent } \\
\text { Aggregate/ } \\
\text { sand ( dry wt- } \\
\text { \%) }\end{array}$ & $\begin{array}{c}\text { Reducing } \\
\text { Equivalents } \\
\text { ( } \mu \text { eq/g) }\end{array}$ \\
\hline Aged Cement & NA & NA & NA & NA & $85.5 \pm 10.1^{(\mathrm{a})}$ \\
\hline $\begin{array}{l}\text { Vault } 2 \\
\text { Cement }^{(\mathrm{d})}\end{array}$ & 17 & 13 & 10 & 58 & $178^{(\mathrm{b})}$ \\
\hline TR547 & 45 & 10 & 45 & 0 & $607^{(\mathrm{b})}$ \\
\hline TR545 & 90 & 10 & 0 & 0 & $681^{(\mathrm{b})}$ \\
\hline $\begin{array}{l}\text { Blast Furnace } \\
\text { Slag }\end{array}$ & 100 & 0 & 0 & 0 & $819^{(\mathrm{b})}$ \\
\hline $\begin{array}{l}\text { Blast Furnace } \\
\text { Slag }\end{array}$ & 100 & 0 & 0 & 0 & $832^{\text {(a) }}$ \\
\hline $\begin{array}{l}\text { Portland } \\
\text { Cement }\end{array}$ & 0 & 100 & 0 & 0 & $198^{(\mathrm{b})}$ \\
\hline Fly Ash & 0 & 0 & 100 & 0 & $299^{(b)}$ \\
\hline \multicolumn{6}{|c|}{$\begin{array}{l}\text { (a) Kaplan et al. (2008) } \\
\text { (b) Roberts and Kaplan (2009) } \\
\text { (c) All percentages of saltstone formulations are reported on a dry weight percentage basis, that is, } \\
\text { the weight of the ingredients before water was added. } \\
\text { (d) Based on Table } 8 \text { in Dixon et al. (2008; SRNL-STI-2008-00421), which shows the following } \\
\text { quantity (lbs/cu yd) for saltstone Vault } 2 \text { Mix } 1 \text { concrete formulation: } 201 \text { cement (12.71 wt-\%), } \\
268 \text { slag ( } 16.95 \text { wt-\%), } 44.7 \text { silica fume ( } 2.83 \text { wt-\%), } 156.3 \text { fly ash }(9.89 \text { wt-\%), } 911 \text { fine sand } \\
\text { ( } 57.62 \text { wt-\%). The large aggregate was removed before the sorption tests were conducted. The } \\
\text { large aggregate accounted for } 75 \text { wt- } \% \text { of the original field sample, not the sample used in these } \\
\text { test, before water was added to the mix. }\end{array}$} \\
\hline
\end{tabular}

\subsection{Methods}

\subsubsection{Experimental Conditions and Apparatus}

All experiments were performed in an anaerobic glovebag with approximately $0.1 \% \mathrm{H}_{2}(\mathrm{~g}) / 99.9 \%$ $\mathrm{N}_{2}$ (g). This was found to be an optimal $\mathrm{H}_{2}$ (g) concentration to maintain the desired reducing conditions described below. A first set of experiments performed with $100 \% \mathrm{~N}_{2}$ (g) atmosphere within the glovebag were unsuccessful. Most likely, oxygen diffusion into the bag resulted in oxidizing conditions within the samples and therefore minimal sorption of ${ }^{99} \mathrm{Tc}(\mathrm{VII})$ was observed. The $K_{d}$ values were similar to those measured under oxidizing conditions with samples having oxidizing Eh values $>100 \mathrm{mV}$ (Lilley et al., 2009, SRNL-STI-2009-00636). Therefore, to reach mildly reducing conditions the $0.1 \% \mathrm{H}_{2}(\mathrm{~g})$ atmosphere was maintained. In order for the glovebag to maintain anaerobic conditions, a palladium catalyst is used inside the bag. The catalyst converts $\mathrm{O}_{2}(\mathrm{~g})$ to water via reaction with $\mathrm{H}_{2}(\mathrm{~g})$. Therefore, the small amount of $\mathrm{H}_{2}(\mathrm{~g})$ is necessary to counter $\mathrm{O}_{2}$ (g) diffusion into the bag.

The oxidation/reduction potential was measured with a Pt redox combination electrode with a $\mathrm{Ag} / \mathrm{AgCl}$ reference in $4 \mathrm{M} \mathrm{KCl}$. Ag/AgCl redox potentials were converted to Eh (Standard Hydrogen Electrode, SHE) values by adding $200 \mathrm{mV}$ to the value measured with the $\mathrm{Ag} / \mathrm{AgCl}$ 
reference. Aqueous $\mathrm{pH}$ was measured with a Thermo PerpHecT sure-flow electrode. All $\mathrm{pH}$ and Eh data are reported below.

\subsubsection{Sample Preparation and Analysis}

A ${ }^{99}$ Tc working solution was prepared by diluting a stock solution of ${ }^{99}$ Tc (Isotope Products, Valencia, CA) in distilled-deionized water (distilled deionized (DDI) water Resistivity >18 $\mathrm{M} \Omega . \mathrm{cm}$ ). The oxidation state of Tc was not measured. However, based on the aqueous concentration in the DDI water solution, it is reasonable to assume that the Tc existed in as $\mathrm{Tc}(\mathrm{VII})$. The reduced Tc(IV) oxidation state would have a very low solubility under these conditions. The expected concentration of $950 \mathrm{ppb}$ based on the dilution was verified using liquid scintillation counting. The ${ }^{99}$ Tc working solution was used to make $0.01,0.05,0.5,1,2,5$, and $10 \mathrm{ppb}$ standards by dilution using $2 \% \mathrm{HNO}_{3}$. These standards were used to calibrate the Thermo Scientific X Series 2 inductively coupled plasma mass spectrometer (ICP-MS) for quantification of ${ }^{99}$ Tc. The instrument performance was monitored by interpolating between ${ }^{89} \mathrm{Y}$ and ${ }^{115} \mathrm{In}$ internal standards. The recovery of each sample during analysis was corrected based on the internal standard recovery. The internal standard recoveries remained within standard quality assurance/quality control (QA/QC) protocols for the instrument (between 80\% and 120\%).

For each of the four solids, two sets of triplicate samples were prepared with ${ }^{99} \mathrm{Tc}(\mathrm{VII})$ concentrations of $2.5 \mathrm{ppb}$ and $10 \mathrm{ppb}$. A set of no solids controls at initial concentrations of 2.5 $\mathrm{ppb}$ and $10 \mathrm{ppb}{ }^{99} \mathrm{Tc}$ were also prepared in triplicate. Samples were prepared in Falcon BlueMax $50 \mathrm{~mL}$ polypropylene vials. A 1.0 g aliquot of solid was added to the tube followed by $40 \mathrm{~mL}$ of saturated calcite solution. The resulting solutions were then spiked with ${ }^{99} \mathrm{Tc}(\mathrm{VII})$ to either 2.5 ppb or $10 \mathrm{ppb}$ and shaken end-over-end. The point at which the ${ }^{99} \mathrm{Tc}$ (VII) amendment was made was considered time zero. These spike concentrations were selected because they were easy to detect (they would provide sufficient range to permit detecting ${ }^{99}$ Tc several orders of magnitude lower than the spike concentration). Equally important, these spike concentrations are close to actual concentration measured in actual samples recovered from the Saltstone Facility. Almond et al. (2011) recovered samples with Tc concentrations of 5.35e-11 Ci/g in the solid phase and when leached under oxidized conditions to measured $\mathrm{K}_{\mathrm{d}}$ values $\left(\mathrm{K}_{\mathrm{d}}=12 \mathrm{~mL} / \mathrm{g}\right)$ the aqueous phase had $2.82 \mathrm{e}-12 \mathrm{Ci} / \mathrm{mL}$ or $0.16 \mathrm{ppb}{ }^{99} \mathrm{Tc}$. Most of the aqueous phase ${ }^{99} \mathrm{Tc}$ values measured in contact with saltstone in these studies were equal to or below this concentration because they were measured under reducing conditions that promote adsorption and precipitation.

At 1, 4, 8, 19, and 56 days after spiking with ${ }^{99} \mathrm{Tc}$, approximately $2 \mathrm{~mL}$ of each suspension was recovered. Care was taken to remove a homogenous sample of the saltstone suspension to prevent changing the aqueous/solid ratio in the sample. The $2 \mathrm{~mL}$ aliquot was passed through a $200 \mathrm{~nm}$ PTFE filter and the first milliliter was discarded. A $1.0 \mathrm{~mL}$ aliquot of the filtrate was then diluted with $9 \mathrm{~mL} 2 \% \mathrm{HNO}_{3}$ and the soluble ${ }^{99}$ Tc concentration was determined using ICP-MS as discussed above. The Eh and $\mathrm{pH}$ of the remaining suspensions were measured and recorded at each sampling interval. 
SRNL-STI-2011-00716

Revision 0

\subsection{Results and Discussion to Date}

\subsection{1 ${ }^{99}$ Tc Batch Sorption Experiments}

The fraction of aqueous ${ }^{99} \mathrm{Tc}$ in the four cementitious solid suspensions as well as the no solids blanks are plotted in Figure 1. The data are also presented with $K_{d}$ on the $y$-axis in Figure 2. As expected based on the high solubility and low sorption affinity of ${ }^{99} \mathrm{Tc}(\mathrm{VII})$, there was little loss of ${ }^{99} \mathrm{Tc}$ to the container walls in the no solids control samples presented in Figure 1. (It is not necessary to have to assume a speciation for Tc, but due to the high concentrations in the no solids controls, and the lack of sorption to the slag-free Aged cement, it is likely that the original spike was $\mathrm{TcO}_{4}{ }^{-}$.) The data in tabular format is presented in Appendix $\mathrm{B}$. At the end of the study, aqueous suspensions will be analyzed the ratio of $\mathrm{Tc}(\mathrm{VII} / \mathrm{IV})_{\mathrm{aq}}$ in the aqueous phase to confirm experimental results.

In samples containing cementitious solids, sorption generally increased with increasing slag content in the solid. There is little sorption of ${ }^{99} \mathrm{Tc}$ to the aged cement sample. The high amount of ${ }^{99}$ Tc sorption to the Vault 2 solid (17\% slag) at 56 days was somewhat unexpected due to the low slag content, with respect to TR547 (45\% slag). However, at early sampling points, there is clearly greater sorption of ${ }^{99}$ Tc to TR545 and TR547. It is unclear what is causing the relatively strong sorption to the Vault 2 sediment at extended times. It is noteworthy that similar elevated ${ }^{99}$ Tc uptake compared to TR545, containing a higher concentration of slag, was also observed under more reducing conditions (Lilley et al., 2009, SRNL-STI-2009-00636).

Data in Figure 2 show that there is a slight difference in the $\mathrm{K}_{\mathrm{d}}$ values between the $2.5 \mathrm{ppb}$ and 10 ppb ${ }^{99} \mathrm{Tc}$ loadings for the same solid. This is somewhat unexpected because the $\mathrm{K}_{\mathrm{d}}$ values should be independent of total analyte concentration. However, these are the initial data points and the systems have clearly not reached equilibrium. Therefore, the observed difference in $K_{d}$ values may be a manifestation of ${ }^{99} \mathrm{Tc}$ concentration dependence on the sorption kinetics. It is noteworthy that the relatively large $\mathrm{K}_{\mathrm{d}}$ variations in Figure 2 are the result of relatively small differences in fraction sorbed (Figure 1; Appendix B). Additionally, there is not a consistent trend, whereby one spike concentration produces a greater or lower relative $\mathrm{K}_{\mathrm{d}}$ value. So as not to over interpret the data, it may be best to wait until the system comes closer to steady state before further comment on the importance of spike concentration. The average for both spike concentrations (average of 6 values):

- $\quad$ Aged Cement $\mathrm{K}_{\mathrm{d}}=-14 \mathrm{~mL} / \mathrm{g}$,

- Vault $2 \mathrm{~K}_{\mathrm{d}}=6,362 \mathrm{~mL} / \mathrm{g}$,

- $\quad$ TR547 Saltstone ( $45 \%$ slag) $=1,258 \mathrm{~mL} / \mathrm{g}$

- $\quad$ TR545 Saltstone $(90 \%$ slag $)=12,112 \mathrm{~mL} / \mathrm{g}$

The $\mathrm{pH}$ and redox potentials measured at each sampling interval are provided in Figure 3 and Figure 4, respectively. As expected, the $\mathrm{pH}$ values of the four cementitious materials were between 11.25 and 12.25 (Figure 3). They did not vary as a function of time. The no solids control did change during the course of the study, likely as a result of changes in the redox status (Figure 4). Generally, as Eh increases, $\mathrm{pH}$ in aqueous systems decreases. 
The Eh of all five systems, regardless of whether they contained slag or not, during the first 19 days of the study, had Eh values of about -400 (Figure 4). By the time the next measurement was taken, day 56, the Eh of the two slag-free systems (no solids controls and the aged cement) increased substantially to above zero $\mathrm{mV}$. The cause for this is not known but it is possible that the reductant (perhaps $\mathrm{H}_{2}$ originating from the glovebag atmosphere) was eventually dissipated or consumed and the system returned to its expected redox state. The slag containing systems, the Vault 2 and the two saltstone samples, remained at very low Eh values. There is essentially no ${ }^{99}$ Tc sorption to these slag-free systems, so it is not surprising that ${ }^{99}$ Tc sorption to these two systems did not change significantly at day 56.

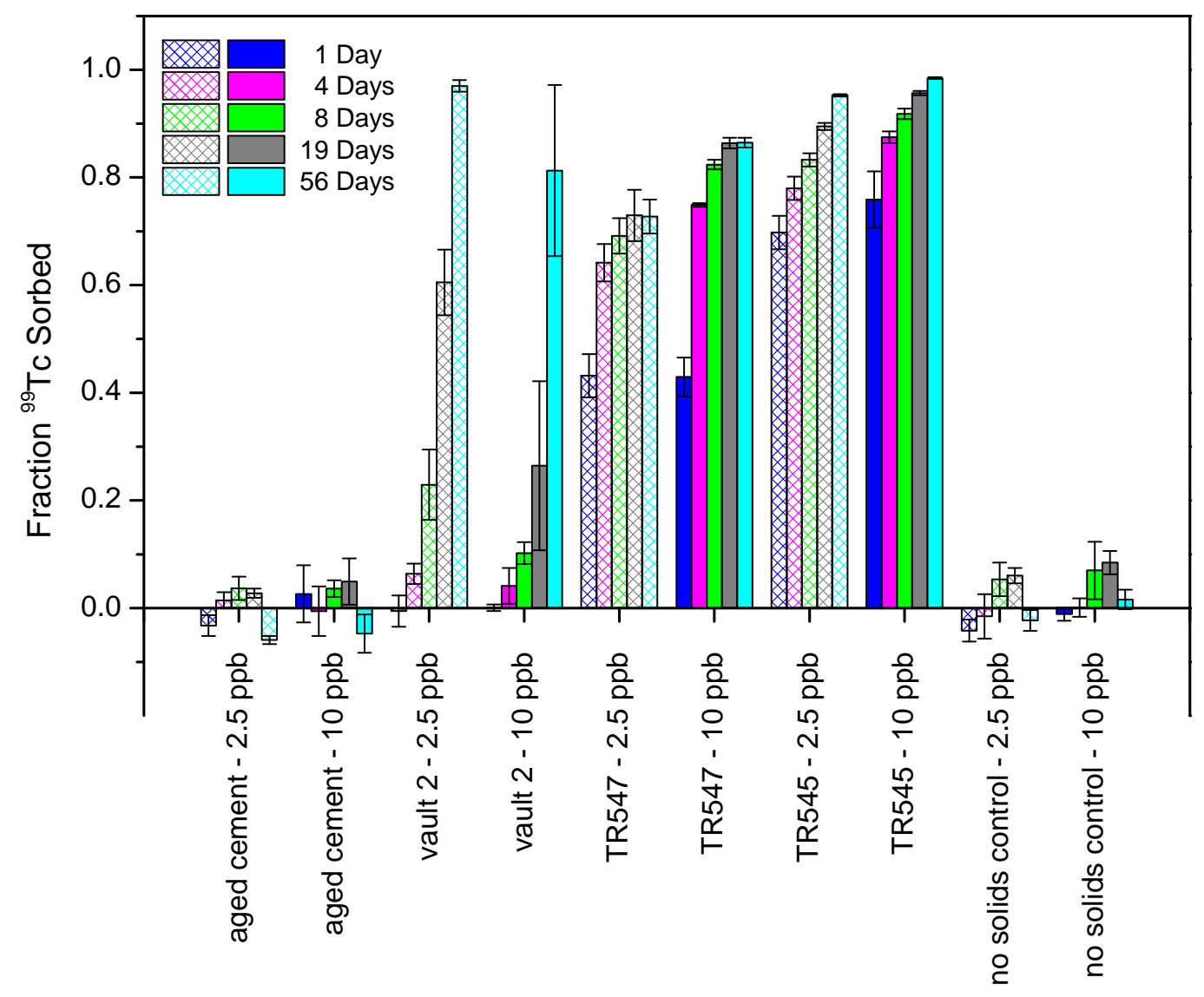

Figure 1. Fraction of ${ }^{99}$ Tc sorbed as a function of time and cementitious materials (X-axis labels note which cementitious material was used and the total ${ }^{99}$ Tc concentration). 


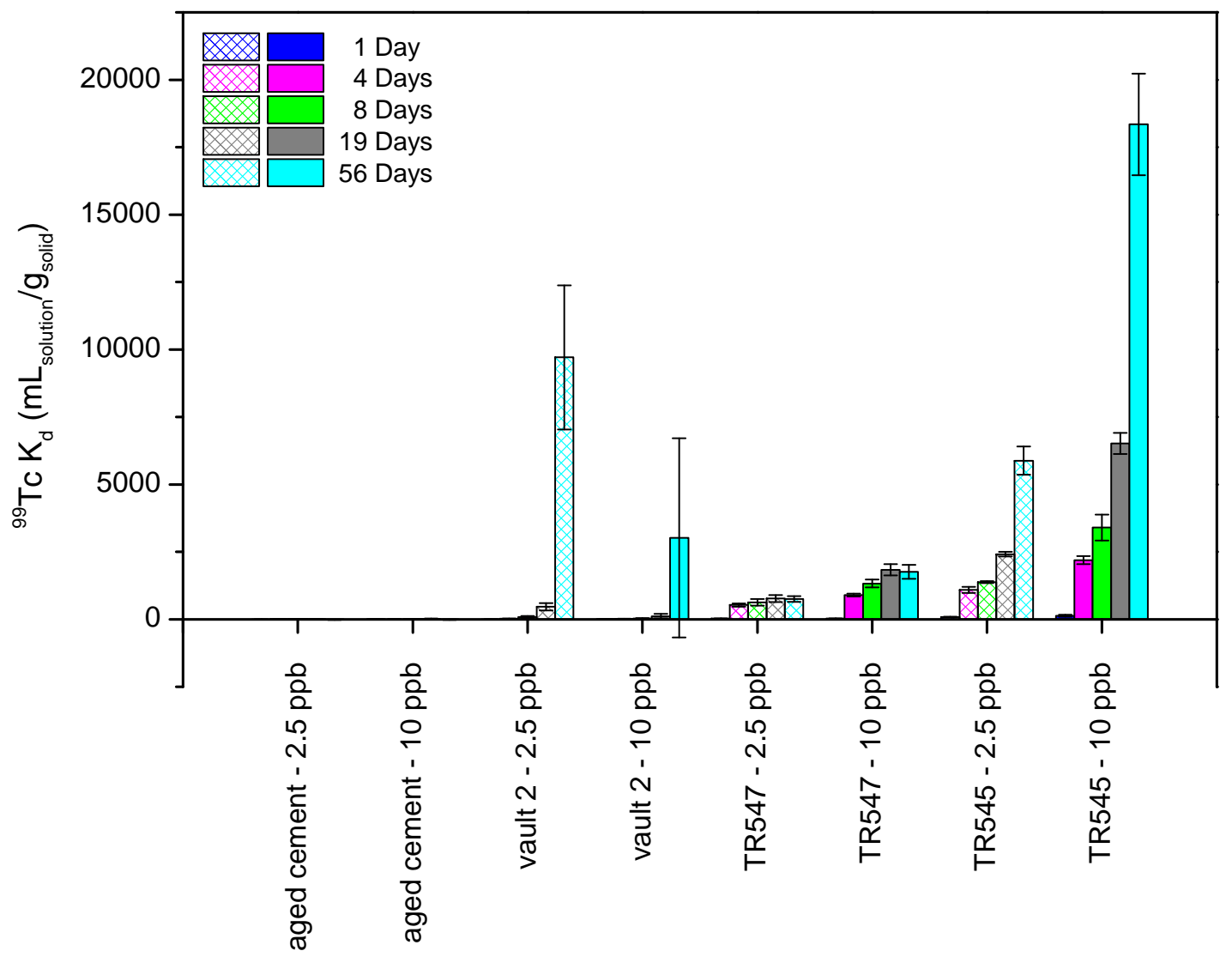

Figure 2. Conditional $K_{d}$ values (i.e., non-equilibrium) as a function of time measured for ${ }^{99}$ Tc sorption to cementitious materials (X-axis labels note which cementitious material was used and the total ${ }^{99}$ Tc concentration). 


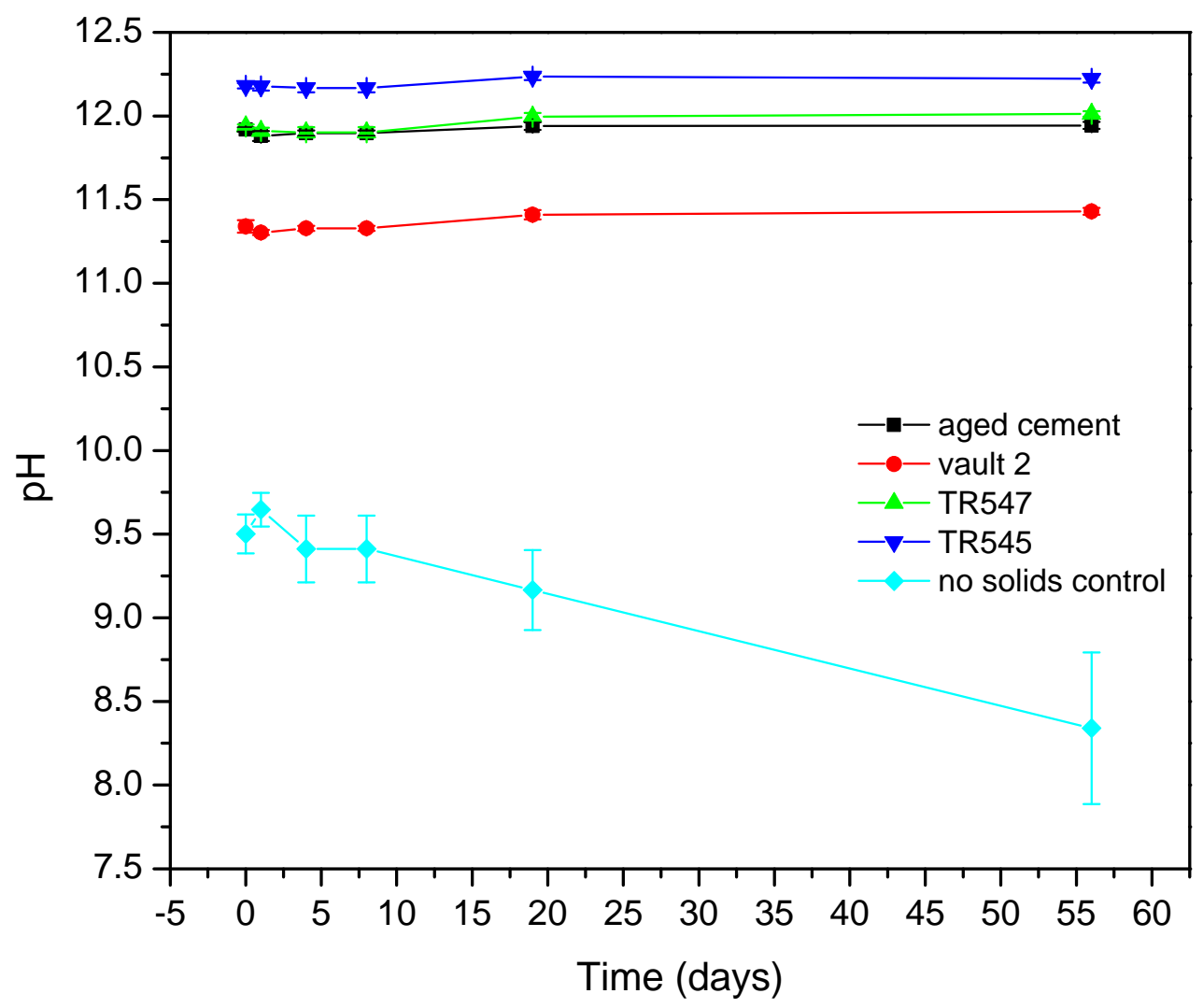

Figure 3. pH of cementitious material suspensions measured during ${ }^{99}$ Tc sorption experiments. 


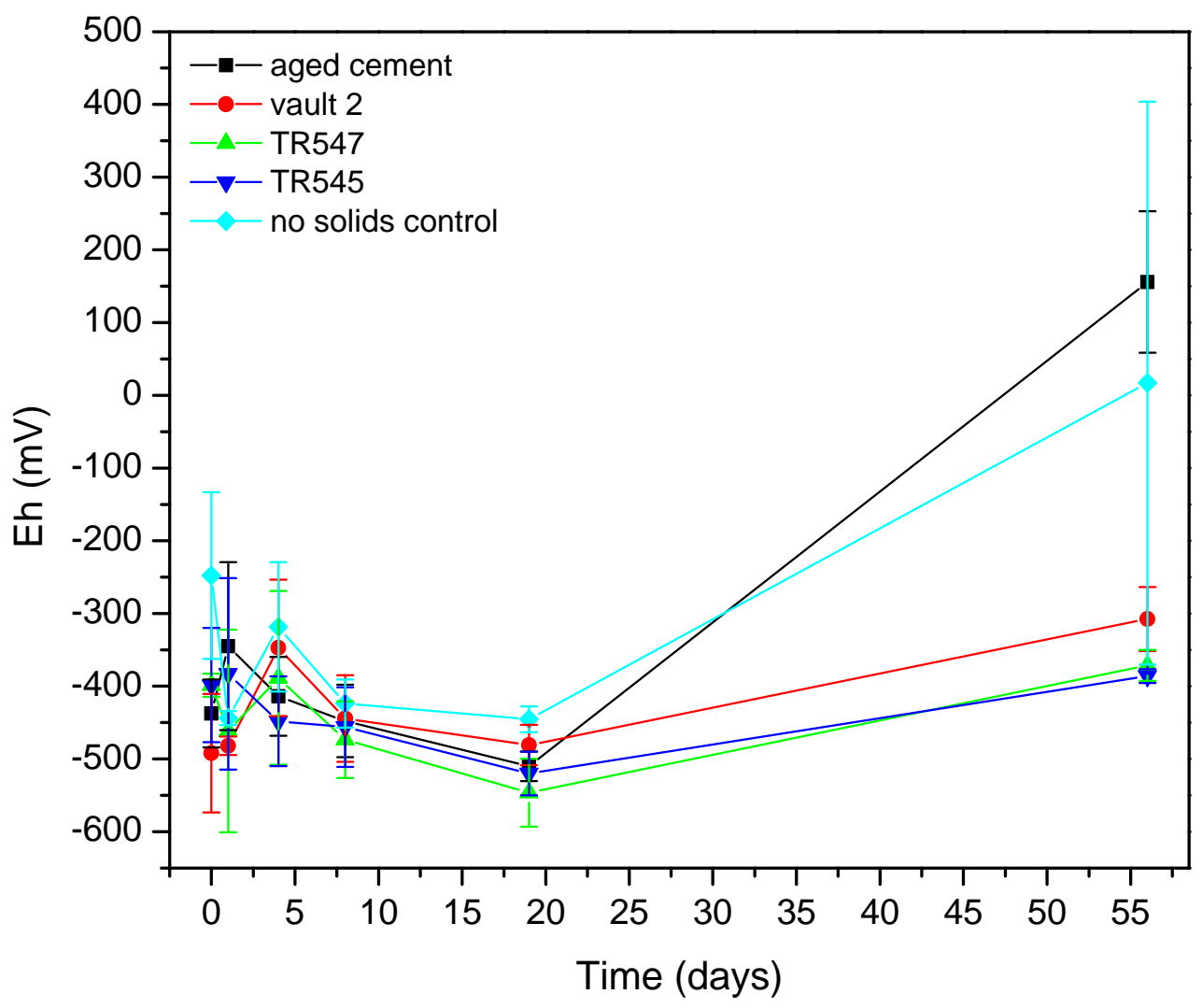

Figure 4. Redox potentials (converted to SHE) of cementitious material suspensions measured during ${ }^{99} \mathrm{Tc}$ sorption experiments.

\subsubsection{Submission of Proposal for XAS Beamline Time}

A proposal for beamline time to examine the redox state of $\mathrm{Fe}, \mathrm{S}$, and $\mathrm{Cr}$ (non-rad) to understand the measure oxidation rate and understand chemistry/mineralogy responsible redox chemistry was conditionally approved for the end of January 2012. A copy of the submitted proposal is provided in Appendix A. A follow up proposal in the coming year will be written to examine the Tc redox state. 
SRNL-STI-2011-00716

Revision 0

\subsection{Conclusions}

Tc sorption experiments to cementitious materials in an anaerobic glovebag were conducted to provide input for the performance assessment of Tc in saltstone. Many controls and ancillary measurements were included in the study. Among the more important observations were that Tc did not sorb to the no-solid control glassware and slag-free cementitious material Tc sorption tended to increase with increasing slag content in the cementitious material formulation (with one notable exception). After 56 days of contact, it had been demonstrated that $\mathrm{pH}$ had obtained a steady state in the saltstone samples, but it was not demonstrated that Tc had obtained a steady state, evidenced by increasing $K_{d}$ values. Different Tc $K_{d}$ values between the two spike concentrations were observed, for some solids the more dilute spike yielded a higher $\mathrm{K}_{\mathrm{d}}$ value and for other solids, the opposite was true. Therefore, the observed difference in $K_{d}$ values may be a manifestation of ${ }^{99} \mathrm{Tc}$ concentration dependence on the sorption kinetics. It is noteworthy that the relatively large $K_{d}$ variations in Figure 2 are the result of relatively small differences in fraction sorbed Figure 1.

At this writing, this study continues in the anaerobic glovebag and approximately four more samples are anticipated to be collected. At the end of the experiment, the system will be taken out of the glovebag and air will be sparged into the system. The reverse reaction of Tc desorption from the cementitious materials caused by $\mathrm{Tc}(\mathrm{IV})$ oxidation by $\mathrm{O}_{2}(\mathrm{~g})$ to $\mathrm{TcO}_{4}{ }^{-}$will be measured. Additionally, some of the anaerobic glovebag samples will be saved for analysis for future synchrotron X-ray absorption spectroscopy (XAS) studies.

\subsection{References}

Almond, P. M., D. I. Kaplan. 2011. Distribution Coefficients $\left(\mathrm{K}_{\mathrm{d}}\right)$ Generated from a Core Sample Collected from the Saltstone Disposal Facility. SRNL-STI-2010-00667. Savannah River National Laboratory, Aiken, SC.

Dixon, K., J. Harbour, M. Phifer. 2008. Hydraulic and Physical Properties of Saltstone Grouts and Vault Concretes.SRNL-STI-2008-00421. Savannah River National Laboratory, Aiken, SC.

Kaplan, D. I., Coates, J. M., Siegfried, M, Roberts, K., Serkiz, S. 2008. Saltstone and Radionuclide Interactions: Technetium Sorption and Desorption, Saltstone Reduction Capacity, and Radionuclide Sorption $\left(\mathrm{K}_{\mathrm{d}}\right)$ Value. SRNS-STI-2008-00045. Savannah River National Laboratory, Aiken, SC.

Kaplan, D. I., M. S. Lilley, P. M. Almond, and B. A. Powell. 2011. Long-term Technetium Interactions with Reducing Cementitious Materials. SRNL-STI-2010-00668. Savannah River National Laboratory, Aiken, SC.

Lilley, M. 2010. Determination of Sorption Coefficients for Neptunium, Plutonium, Iodine, and Technetium in Engineered and Natural Systems under Oxidizing and Reducing Conditions. Masters Degree Thesis. Clemson University, Clemson, SC. 
Lilley, M. S., B. A. Powell, and D. I. Kaplan. 2009. Iodine, Neptunium, Plutonium, and Technetium Sorption to Saltstone Under Oxidizing and Reducing Conditions. SRNL-STI2009-00636. Rev.0, Savannah River National Laboratory, Aiken, SC.

Roberts, K. A. and D. I Kaplan. 2008. Reduction Capacity of Saltstone and Saltstone Components. SRNL-STI-2009-00637. Savannah River National Laboratory, Aiken, SC. 
SRNL-STI-2011-00716

Revision 0

\section{Appendix A: Submitted X-ray Absorption Spectroscopy Proposal}




\section{SSRL LETTER OF INTENT PROPOSAL FORM}

\section{BRIEFLY STATE WHY YOU ARE SUBMITTING A LETTER OF INTENT (LOI)} PROPOSAL RATHER THAN A STANDARD PROPOSAL (Note: LOIs may be requested under a limited set of conditions. In general, the LOI is used to test feasibility of a "risky" experiment; however, it can be used for novel ideas requiring only a small of amount of beam time and which have been conceived too late for the normal review cycle. LOIs do not go through the full review process, but may receive assignment of beam time (usually $\sim 6-12$ shifts) at the discretion of the SSRL Director or on the advice of the PRP. Staff members review LOIs to identify and address any technical or safety issues. In general, rated proposals take priority over LOIs in the scheduling process.)

We are interested in studying redox chemistry of ${ }^{99} \mathrm{Tc}$ in cementitious materials. Due to the super redox sensitive nature of reduced Tc, we would like to test feasibility of our redox transport chamber from SC to CA using non-rad samples before we formally submit a full proposal to SSRL. In this rapid access proposal, redox sensitive field simulated saltstone-slag samples will be used to conduct bulk Fe, S and Cr K-edge XANES measurements at BL4-1/4-3.

\section{TITLE: Kinetics and Mechanistic of Technetium Redox Chemistry in Reducing Cementitious Materials}

3. SPOKESPERSON and COLLABORATORS: (list spokesperson first)

\begin{tabular}{|c|c|c|c|c|c|}
\hline Full Name & Full Institution \& Address & Work Phone & Fax Number & E-mail Address & Degree \\
\hline Yuji Arai & $\begin{array}{l}\text { Clemson University } \\
270 \text { P\&A }\end{array}$ & $864-656-2607$ & & yarai@clemson.edu I & Ph.D \\
\hline Brian Powell & $\begin{array}{l}\text { Clemson, SC } 29634 \\
\text { Clemson University } \\
\text { Rich Lab, } 342 \text { Computer Court } \\
\text { Anderson, SC } 29625\end{array}$ & 864.656 .1004 & & bpowell@cemson.edu & $1 \quad \mathrm{Ph} . \mathrm{D}$ \\
\hline Daniel Kaplan & Savannah River National Laboratory & $803-725-2363$ & & daniel.kaplan@sml.doe.gc & ov $\mathrm{Ph} . \mathrm{D}$ \\
\hline
\end{tabular}

4. BRIEFLY DESCRIBE THE PROBLEM TO BE STUDIED: (Please limit to $300 \mathrm{words} / 2000$ characters):

Cementitious materials (CMs) are an important component of the strategy to stabilize nuclear waste resulting from plutonium production by DOE. In particular, ${ }^{99} \mathrm{Tc}$ is one of major risk drivers at the Saltstone Facility at DOE Savannah River Site (SRS). Because of high solubility of Tc(VII) in aerobic environments, the conversion of $\mathrm{Tc}(\mathrm{VII})$ to $\mathrm{Tc}(\mathrm{IV})$ is required to immobilize $\mathrm{Tc}$ in the $\mathrm{CMs}$. The recent shrinking core computer model showed the existence of a sharp boundary that consisted of oxidized outer layer of concrete surrounding a shrinking core of reducing intact saltstone. The slow movement of the boundary seems to be the key to predict the re-mobilization of Tc in the CMs. Unfortunately the current shrinking core model is devoid of geochemical mechanisms. Detail kinetics, mechanisms, and input values are needed to reduce uncertainties in future detailed modeling. The objective of this study is to clarity regarding the process and mechanisms of redox reactions via XAS analysis to improve the Tc stabilization technology in CMs. In our recent laboratory investigation, it was found that $\mathrm{Tc}(\mathrm{IV})$ instantaneously oxidized in field simulated slag-containing saltstone $(<1 \mathrm{~mm}$ fraction) with only trace concentrations of atmospheric oxygen $\left(\sim 30 \mathrm{ppm} \mathrm{O}_{2}\right.$; Eh $\left.120 \mathrm{mV}\right)$ at the high pH, suggesting the super redox sensitive nature of Tc(IV). Prior to the preparation of Tc samples with waste simulant using betaemitter ${ }^{99} \mathrm{Tc}$, we are first interested in testing our redox sample transport chamber from Dr. Kaplan's SR National laboratory, Aiken, SC to SSRL, Menlo Park, CA. It consists of five layers of polycarb/glass jar barriers with oxygen scrubbers and sensor strips in each layer. In this rapid access proposal, we will test feasibility of the chamber using field simulated non-rad saltstone-slag samples. As redox indicators, we will conduct bulk XANES measurements at Fe, S and Cr K-edge at BL4-1/4-3. 
SRNL-STI-2011-00716

Revision 0

\author{
5. TIME FRAME DESIRED: \\ Nov-Feb Cycle \\ 6. EXPERIMENTAL STATIONS DESIRED: \\ (If two stations required, list both under first choice.)
}

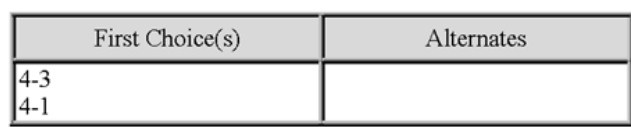

7. ESTIMATED BEAM TIME REQUIRED IN 8-HOUR SHIFTS:

5 shifts

\title{
8. REQUIRED CRYSTAL SET AND ORIENTATION:
}

$\mathrm{Si}(111) \mathrm{Phi}=0$

9. SSRL EQUIPMENT OR MATERIALS REQUESTED

Standard XAS configuration, Lytle, GE13, Cryo-set up

For $\mathrm{S}$ k-edge XAS, He purged chamber

10. POTENTIAL SAFETY CONCERNS OR HAZARDS

$\mathrm{X}$ No hazardous substances, equipment, or procedure will be brought to SSRL as part of this proposed experiment.

IF YES, please complete safety questions below. Additionally, provide detailed safety procedures in proposal text.

Chemical Use () NO (X)Yes

Subtance:_ a mixture of $\mathrm{Al2O} 2, \mathrm{Fe} 2 \mathrm{O} 3, \mathrm{SiO} 2$

Common Name: Slag containing saltstone with cement

NANOSCALE MATERIALS USE? (X)No ()Yes

- If yes, will there be open manipulation of nanoscale material samples at SSRL? (X)No ()Yes

- If no, how are the samples contained?_Sealed with kapton/myler tape

- If yes, a safety plan must be submitted to the SSRL Safety Office for approval. See CDC/NIOSH website for guidance http://www.cdc.gov/niosh/topics/nanotech/safenano/

BIOHAZARDOUS MATERIALS USE? (X)No ()Yes

- If yes, what type \&\& what is the materials NIH classification

HUMAN OR ANIMAL SUBJECT USE? (X)No ()Yes

- If yes, what type ___ " "Please contact SSRL Safety Office for further guidance.

RADIOACTIVE MATERIALS USE? (X)No () Yes*

- If yes, what is the materials specific activity

*Radioactive substances may not be brought directly to SSRL. They first must be shipped or taken to Operational Health Physics, Bldg. 24, MS 84, 2575 Sand Hill Rd., Menlo Park, CA 94025, or contact Ray Russ at 650-926-4768.

LASER USE? (X)No ()Yes

- If yes, ANSI classification

Laser hazards controls you will apply:

Wavelength:

Total power:

HAZARDOUS EQUIPMENT/ELECTRICAL EQUIPMENT? ()No ()Yes

- If yes, describe hazardous/electrical equipment you will be bringing to SSRL. Indicate if it is a commercial product, certified, and if it has been altered in any way.

11. WILL THESE EXPERIMENTS INVOLVE TISSUE FROM HUMAN SUBJECTS OR LABORATORY ANIMALS? (X)No $\square$ Yes, provide details. 
12. WILL PRIVATE SECTOR RESEARCH BE PERFORMED? X No

$\square$ Yes

(Note that private sector research is subject to specific terms and conditions, and SSRL must be reimbursed at full cost recovery.

Please complete the Supplemental Use Agreement for Private Sector Research.)

13. REQUIRED FOR DOE REPORTING PURPOSES:

\begin{tabular}{|l|l|l|l|l|l|l|}
\hline \multicolumn{5}{|c|}{ RESEARCH AREA (check all that apply) } & & Engineering \\
\hline & Materials Science & & Polymers & & Earth Sciences & \\
\hline & Physics & & Medical Applications & & Environmental Sciences & Development \\
\hline & Other: (specify) & $\begin{array}{l}\text { Biological and Life } \\
\text { Sciences }\end{array}$ & Optics & $\begin{array}{l}\text { Purchase of Specialty } \\
\text { Services or Materials }\end{array}$ \\
\hline \multicolumn{5}{|c|}{ FUNDING AGENCY (check all that apply) } & Fdn/Research Inst. \\
\hline & DOE/BES & & DVA & NSF & State/County/City \\
\hline & DOE/BER & NASA & USDA & Prof/Voluntary Assoc. \\
\hline & DOE Other: (specify) & $\mathrm{X}$ & NIH & & Other US Gov't: (specify) & Foreign: (specify) \\
\hline
\end{tabular}

14. HAS A PROPOSAL COVERING THIS RESEARCH been submitted to other synchrotron radiation facilities? If so, which? Are there particular capabilities of SSRL that are required for portions of this research?
15. HAVE YOU RECEIVED BEAM TIME AT SSRL IN THE PAST?
X YES
$\square \mathrm{NO}$

16. IF YOU HAVE PREVIOUSLY RECEIVED BEAM TIME AT SSRL, HAVE YOU NOTIFIED SSRL OF ALL OF YOUR SSRL RELATED PUBLICATIONS, PATENTS AND/OR AWARDS? X YES $\quad \square$ NO If not previously reported, list below or append to this proposal information on publications, patents, and awards that resulted from your prior beam time at SSRL (refer to lists at www-ssrl.slac.stanford.edu/pubs/)

17. IF YOU PUBLISHED RESULTS RELATED TO YOUR SSRL BEAM TIME, DID YOU ACKNOWLEDGE SSRL AND FUNDING SOURCES IN THESE PUBLICATIONS? X YES $\square$ NO (If not already

done, please refer to instructions and sample acknowledgements at www-ssrl.slac.stanford.edu/pubs)

18. DO YOU HAVE ANY SUGGESTIONS OR CONCERNS WHICH YOU WOULD LIKE TO SHARE WITH SSRL, THE PROPOSAL REVIEW PANEL, OR THE SSRL USERS' ORGANIZATION EXECUTIVE COMMITTEE?

This research is deemed to be of interest to the DOE and falls within the scope of the BES mission.

\begin{tabular}{|l|l}
\hline Chi Chang Kao, SSRL Director & Date: \\
\hline
\end{tabular}


SRNL-STI-2011-00716

Revision 0

Appendix B: Data for Tc-99 Fraction Sorbed and $K_{d}$ Values 
Tc-99 sorption data from 1-day

\begin{tabular}{|c|c|c|c|c|}
\hline description & $\begin{array}{c}\text { Fraction } \\
\text { Tc99 } \\
\text { Sorbed }\end{array}$ & $\begin{array}{c}\text { Stdev in } \\
\text { Fraction } \\
\text { Sorbed }\end{array}$ & $\mathrm{Kd}$ & Kd error \\
\hline & & & $\mathrm{mL}_{\text {soln }} / \mathrm{g}_{\text {solid }}$ & \\
\hline & \multicolumn{4}{|c|}{$1 \mathrm{DAY}$} \\
\hline aged cement - $2.5 \mathrm{ppb}$ & -0.03244 & 0.01933 & -1.21176 & 0.72116 \\
\hline aged cement - $10 \mathrm{ppb}$ & 0.02645 & 0.0531 & 1.09701 & 2.05575 \\
\hline vault $2-2.5 \mathrm{ppb}$ & -0.00561 & 0.02916 & -0.11487 & 1.1828 \\
\hline vault $2-10 \mathrm{ppb}$ & $6.12 \mathrm{E}-04$ & 0.00606 & 0.02068 & 0.22721 \\
\hline TR547 - $2.5 \mathrm{ppb}$ & 0.43182 & 0.04009 & 27.89884 & 2.78046 \\
\hline TR547 - 10 ppb & 0.42944 & 0.03625 & 27.88672 & 2.63982 \\
\hline TR545 - $2.5 \mathrm{ppb}$ & 0.69777 & 0.03119 & 85.69119 & 7.97998 \\
\hline TR545 - $10 \mathrm{ppb}$ & 0.75915 & 0.05251 & 128.82067 & 37.90061 \\
\hline no solids control - $2.5 \mathrm{ppb}$ & -0.04177 & 0.02072 & & \\
\hline no solids control - $10 \mathrm{ppb}$ & -0.01126 & 0.0124 & & \\
\hline
\end{tabular}

Tc-99 sorption data from 4-days

\begin{tabular}{|c|c|c|c|c|}
\hline description & $\begin{array}{c}\text { Fraction } \\
\text { Tc99 } \\
\text { Sorbed }\end{array}$ & $\begin{array}{c}\text { Stdev in } \\
\text { Fraction } \\
\text { Sorbed }\end{array}$ & $\mathrm{Kd}$ & Kd error \\
\hline & & & $\mathrm{mL}_{\text {soln }} / \mathrm{g}_{\text {solid }}$ & \\
\hline & \multicolumn{4}{|c|}{4 DAYS } \\
\hline aged cement - $2.5 \mathrm{ppb}$ & 0.01467 & 0.01456 & 4.57554 & 4.55323 \\
\hline aged cement - $10 \mathrm{ppb}$ & -0.00585 & 0.04623 & -1.63054 & 13.26937 \\
\hline vault $2-2.5 \mathrm{ppb}$ & 0.06366 & 0.0189 & 21.51657 & 10.14945 \\
\hline vault $2-10 \mathrm{ppb}$ & 0.04127 & 0.03316 & 12.9098 & 10.59339 \\
\hline TR547 - $2.5 \mathrm{ppb}$ & 0.64168 & 0.03496 & 528.56757 & 57.0086 \\
\hline TR547 - 10 ppb & 0.74897 & 0.00344 & 894.9199 & 53.88288 \\
\hline TR545 - $2.5 \mathrm{ppb}$ & 0.77992 & 0.02175 & 1087.5399 & 113.424 \\
\hline TR545 - 10 ppb & 0.8745 & 0.01083 & 2190.9056 & 147.7684 \\
\hline no solids control - $2.5 \mathrm{ppb}$ & -0.01553 & 0.04142 & & \\
\hline no solids control - $10 \mathrm{ppb}$ & $7.42 \mathrm{E}-04$ & 0.01715 & & \\
\hline
\end{tabular}


Tc-99 sorption data from 9-days

\begin{tabular}{|c|c|c|c|c|}
\hline description & $\begin{array}{c}\text { Fraction } \\
\text { Tc99 } \\
\text { Sorbed }\end{array}$ & $\begin{array}{c}\text { Stdev in } \\
\text { Fraction } \\
\text { Sorbed }\end{array}$ & $\mathrm{Kd}$ & Kd error \\
\hline & & & $\mathrm{mL}_{\text {soln }} / \mathrm{g}_{\text {solid }}$ & \\
\hline & \multicolumn{4}{|c|}{8 DAYS } \\
\hline aged cement - $2.5 \mathrm{ppb}$ & 0.03661 & 0.02175 & 10.6432 & 6.25125 \\
\hline aged cement - $10 \mathrm{ppb}$ & 0.03614 & 0.0152 & 10.5837 & 4.84007 \\
\hline vault $2-2.5 \mathrm{ppb}$ & 0.22909 & 0.06519 & 86.64781 & 34.81427 \\
\hline vault $2-10 \mathrm{ppb}$ & 0.10216 & 0.02045 & 31.96593 & 5.74778 \\
\hline TR547 - $2.5 \mathrm{ppb}$ & 0.6913 & 0.03289 & 627.68822 & 121.0706 \\
\hline TR547 - 10 ppb & 0.82379 & 0.00878 & 1325.5424 & 146.4248 \\
\hline TR545 - $2.5 \mathrm{ppb}$ & 0.83274 & 0.01223 & 1377.8559 & 32.25954 \\
\hline TR545 - 10 ppb & 0.9182 & 0.0098 & 3397.6545 & 480.3856 \\
\hline no solids control - $2.5 \mathrm{ppb}$ & 0.05319 & 0.0311 & & \\
\hline no solids control - $10 \mathrm{ppb}$ & 0.06987 & 0.0536 & & \\
\hline
\end{tabular}

Tc-99 sorption data from 19-days

\begin{tabular}{|c|c|c|c|c|}
\hline description & $\begin{array}{c}\text { Fraction } \\
\text { Tc99 } \\
\text { Sorbed }\end{array}$ & $\begin{array}{c}\text { Stdev in } \\
\text { Fraction } \\
\text { Sorbed }\end{array}$ & $\mathrm{Kd}$ & Kd error \\
\hline & & & $\mathrm{mL}_{\text {soln }} / \mathrm{g}_{\text {solid }}$ & \\
\hline & \multicolumn{4}{|c|}{19 DAYS } \\
\hline aged cement $-2.5 \mathrm{ppb}$ & 0.02748 & 0.0087 & 8.17959 & 3.09175 \\
\hline aged cement - $10 \mathrm{ppb}$ & 0.04914 & 0.04289 & 15.63513 & 14.77439 \\
\hline vault $2-2.5 \mathrm{ppb}$ & 0.60514 & 0.06107 & 464.99434 & 135.87119 \\
\hline vault $2-10 \mathrm{ppb}$ & 0.26444 & 0.15703 & 113.44554 & 84.00131 \\
\hline TR547 - $2.5 \mathrm{ppb}$ & 0.72964 & 0.04771 & 769.79835 & 130.02696 \\
\hline TR547 - $10 \mathrm{ppb}$ & 0.86381 & 0.00998 & 1833.7149 & 208.42045 \\
\hline TR545 - $2.5 \mathrm{ppb}$ & 0.89483 & 0.00654 & 2411.13544 & 84.63568 \\
\hline TR545 - $10 \mathrm{ppb}$ & 0.95699 & 0.00403 & 6515.64063 & 392.01608 \\
\hline no solids control - $2.5 \mathrm{ppb}$ & 0.06043 & 0.0142 & & \\
\hline no solids control - $10 \mathrm{ppb}$ & 0.0845 & 0.02155 & & \\
\hline
\end{tabular}


Tc-99 sorption data from 56-days

\begin{tabular}{|c|c|c|c|c|}
\hline description & $\begin{array}{c}\text { Fraction } \\
\text { Tc99 } \\
\text { Sorbed }\end{array}$ & $\begin{array}{c}\text { Stdev in } \\
\text { Fraction } \\
\text { Sorbed }\end{array}$ & $\mathrm{Kd}$ & Kd error \\
\hline & & & $\mathrm{mL}_{\text {soln }} / \mathrm{g}_{\text {solid }}$ & \\
\hline & \multicolumn{4}{|c|}{56 DAYS } \\
\hline aged cement - $2.5 \mathrm{ppb}$ & -0.05922 & 0.00754 & -16.06141 & 2.6852 \\
\hline aged cement - $10 \mathrm{ppb}$ & -0.04755 & 0.03565 & -12.78063 & 8.97083 \\
\hline vault $2-2.5 \mathrm{ppb}$ & 0.97018 & 0.01065 & 9707.7195 & 2667.336 \\
\hline vault $2-10 \mathrm{ppb}$ & 0.81294 & 0.15901 & 3018.1118 & 3689.798 \\
\hline TR547 - $2.5 \mathrm{ppb}$ & 0.72753 & 0.03153 & 756.81697 & 106.3774 \\
\hline TR547 - 10 ppb & 0.86464 & 0.00914 & 1759.3226 & 259.1337 \\
\hline TR545 - $2.5 \mathrm{ppb}$ & 0.95264 & 0.00194 & 5878.9646 & 522.3686 \\
\hline TR545 - 10 ppb & 0.98446 & 0.00159 & 18344.844 & 1886.748 \\
\hline no solids control $-2.5 \mathrm{ppb}$ & -0.02308 & 0.01945 & & \\
\hline no solids control - $10 \mathrm{ppb}$ & 0.01599 & 0.01818 & & \\
\hline
\end{tabular}




\section{Distribution:}

P. M. Almond, 773-43A - Rm. 227

A. B. Barnes, 999-W - Rm.336

H. H. Burns, 773-41A - Rm.214

B. T. Butcher, 773-43A - Rm.212

L. B. Collard, 773-43A - Rm.207

A. D. Cozzi, 999-W - Rm.337

D. A. Crowley, 773-43A - Rm.216

S. D. Fink, 773-A - Rm.112

G. P. Flach, 773-42A - Rm.211

B. J. Giddings, 786-5A - Rm.2

J. C. Griffin, 773-A - Rm. A-202

C. C. Herman, 999-W - Rm. 344

R. A. Hiergesell, 773-43A - Rm.218

G. K. Humphries, 705-3C - Rm.206

P. R. Jackson, 703-46A - Rm. 223

D. I. Kaplan, 773-43A - Rm.215

C. A. Langton, 777-42A - Rm.219

D. Li, 999-W - Rm.336

S. L. Marra, 773-A - Rm. A-230

J. Mayer, 773-42A - Rm. 242

F. M. Pennebaker, 773-42A - Rm.146

M. A. Phifer, 773-42A - Rm.252

M. M. Reigel, 999-W - Rm.404

K. A. Roberts, 773-43A - Rm.225

K. H. Rosenberger, 705-1C - Rm.33b

E. P. Shine, 702-41A - Rm. 233

F. G. Smith, III 773-42A - Rm.178

K. H. Subramanian, 766-H - Rm.2204

(1 file copy \& 1 electronic copy), 773-43A - Rm.213 